Article

\title{
Synthesis of Thermo-Responsive Block-Graft Copolymer Based on PCL and PEG Analogs, and Preparation of Hydrogel via Click Chemistry
}

\author{
Pei Shang, Jie Wu, Xiaoyu Shi, Zhidan Wang, Fei Song and Shouxin Liu *(i) \\ Key Laboratory of Applied Surface and Colloid Chemistry, Ministry of Education, School of Chemistry and \\ Chemical Engineering, Shaanxi Normal University, Xi'an 710119, China; sp13772442791@163.com (P.S.); \\ 18375847342@163.com (J.W.); 18647847370@163.com (X.S.); 18189608643@163.com (Z.W.); 17563713257@163.com (F.S.) \\ * Correspondence: liushx@snnu.edu.cn; Tel.: +86-29-81530781
}

Received: 13 March 2019; Accepted: 20 April 2019; Published: 1 May 2019

check for updates

\begin{abstract}
Thermo-responsive cross-linkable $m$ PEG- $b$-[PCL- $g$-(MEO $\left.\left.{ }_{2} \mathrm{MA}-c o-\mathrm{OEGMA}\right)\right]-b-m$ PEG was synthesized by ring-opening polymerization (ROP) and atom transfer radical polymerization (ATRP). Then, the cross-linkable block-graft copolymer was used to prepare hydrogel via a copper-catalyzed 1,3-dipolar azide-alkyne cycloaddition reaction. The chemical structure and composition of copolymer were characterized by proton nuclear magnetic resonance $\left({ }^{1} \mathrm{H} N M R\right)$, Fourier-transform infrared (FT-IR) and gel permeation chromatography (GPC). The self-assembly behaviors of the copolymer in aqueous solution were studied by UV spectrophotometer, fluorescence probes, the surface tension method, dynamic light scattering, and transmission electron microscopy. The results proved that the copolymer has excellent solubility and better temperature response. The three-dimensional network structure of the gels, observed by scanning electron microscopy at different temperatures, indicated that the gels have temperature response.
\end{abstract}

Keywords: $\varepsilon$-Caprolactone; block-graft copolymer; click chemistry hydrogel

\section{Introduction}

An environmentally responsive amphiphilic copolymer, composed of hydrophilic and hydrophobic groups, cannot only self-assemble into core-shell micelles in aqueous solution, but produce correspond alter according to small changes in surrounding, so this copolymer has great potential application in drug delivery $[1,2]$. Hydrogels with three-dimensional network structure have attracted increasing attention because of their unique structure and exceptional properties [3-5]. However, the poor mechanical strength and non-biodegradability of common hydrogels dampen their application in biomedical fields. As is well known, the content of rigid monomer in the comonomer directly affects the properties of amphiphilic polymer; it also influences the swelling and mechanical properties of hydrogel [6]. Therefore, it is necessary to synthesis an environmentally responsive amphiphilic copolymer with suitable monomers, and then to prepare hydrogel by the amphiphilic copolymer $[7,8]$. The special swelling and mechanical properties of the responsive hydrogel, decide that the environmentally responsive hydrogel could be a novel material for many subareas of biomedical, such as drug carriers for controlled-release, tissue engineering, gene delivery, artificial muscles, etc. [9-15].

There are numerous ways to prepare hydrogels, such as free radical polymerization, microemulsion polymerization, "click chemistry" [14], and the like. While, the radical polymerization method has a low monomer conversion rate, and hydrogels produced in this way showed a disordered molecular structure [15]. Microemulsion polymerization has a limited application range [16]. The $\mathrm{Cu}(\mathrm{I})$-catalyzed dipolar cycloaddition reaction of azide-alkyne groups, named "click chemistry", is one of the most 
common methods for synthesizing gel because it can produce various polymers at low-cost [17-19]. In particular, the catalyst of click chemistry is nontoxic to cells, the reaction can be carried out in water or organic solvents, and the speed of the gel formed can be easily controlled. All of the above determined that click chemistry is an ideal method for preparing a three-dimensional network hydrogel [20,21].

It is well known that polyethyleneglycol (PEG) and poly ( $\varepsilon$-caprolactone) (PCL) are widely used in the biomedicine field because of the superior properties that nontoxic, nonimmune, and biodegradable [22-28]. PCL with higher initial strength is used as a toughening biomaterial in bone repair or tissue engineering due to its slow degradation rate and mechanical properties. But, a disadvantage of PCL is its water solubility, which limits the application of PCL-PEG copolymers [29,30]. The PEG analog copolymer was formed by the polymerization of 2-(2-methoxy ethoxy)ethyl methacrylate $\left(\mathrm{MEO}_{2} \mathrm{MA}\right)$ and oligoethylene glycol methyl methacrylate (OEGMA), except it had excellent water solubility similar to PEG, also owning to its unique temperature sensitivity. Moreover, the molar ratio between $\mathrm{MEO}_{2} \mathrm{MA}$ and OEGMA added to the reaction can affect the low critical solution temperature (LCST) of the copolymers [31-33]. Built on the above conditions, this work designed to synthesize a cross-linkable $m$ PEG- $b$-[PCL- $g$-(MEO ${ }_{2}$ MA-co-OEGMA)]- $b$ - $m$ PEG block-graft copolymer, which contains $\mathrm{MEO}_{2} \mathrm{MA}$ and OEGMA monomers to improve the water solubility and temperature sensitivity properties.

In addition, two different cross-linkers were synthesized in this work. The well-defined cross-linker $\mathrm{P}\left(\mathrm{GMA}-\mathrm{co}-\mathrm{MEO}_{2} \mathrm{MA}-c o-\mathrm{OEGMA}\right)$ contained 2-(2-methoxy ethoxy) ethyl methacrylate $\left(\mathrm{MEO}_{2} \mathrm{MA}\right)$ and oligoethylene glycol methyl methacrylate (OEGMA), with the same good water solubility and temperature sensitivity as the $m$ PEG- $b$-[PCL- $g$-( $\mathrm{MEO}_{2} \mathrm{MA}-c o$-OEGMA)]- $b$ - $m$ PEG block-graft copolymer. TPOM is another cross-linker, which has multiple cross-linking points [34]. Then, two kinds of hydrogels with different internal three-dimensional network densities were formed via click chemistry. The two hydrogels have great potential value in the biomedical field.

\section{Materials and Methods}

\subsection{Materials}

$\varepsilon$-Caprolactone (99\%), monomethoxy poly(ethylene glycol) $\left(M_{\mathrm{W}}=750 \mathrm{~g} \cdot \mathrm{mol}^{-1}\right)$, and cuprous chloride were purchased from Alfa Aesar (Shanghai, China). Stannous octoate (Sn(Oct) $2,96 \%$ ), Glycidyl methacrylate (GMA, 99\%), Pentaerythritol (98\%), and Tetrabutylammonium bromide were purchased from J\&k (Beijing, China). Hexamethylene diisocyanate(HMDI), 2-(2-methoxy ethoxy) ethyl methacrylate ( $\left.\mathrm{MEO}_{2} \mathrm{MA}\right)$, and oligoethylene glycol methyl methacrylate (OEGMA) were purchased from TCL. Propargyl bromide, $N$-dodecyl mercaptan, and $N, N, N^{\prime}, N^{\prime}, N^{\prime \prime}$-pentamethyl diethylenetriamine (PMDETA) were purchased from Macleans (Shanghai, China). Sodium azide was purchased from Zhengzhou Penny Chemical Reagent Factory (Zhengzhou, China), 2,2'-bipyridine was purchased from Guangdong Guanghua Technology Co., Ltd. (Guangdong, China). Dichloromethane, $n$-hexane, anhydrous diethyl ether, toluene, methanol, $N$, N-dimethylformamide (DMF), 1,4-dioxane, acetone, and other reagents were purchased from Sinopharm Chemical Reagent Co., Ltd. (Shanghai, China). Among them, $\varepsilon$-Caprolactone should be distilled under reduced pressure situation after being dried over $\mathrm{CaH}_{2}$ for $48 \mathrm{~h}$ at room temperature. All solvents were distilled before used. Methylene chloride was refluxed over $\mathrm{CaH}_{2}$ for $4 \mathrm{~h}$, and then distilled. Toluene was refluxed over sodium for $4 \mathrm{~h}$ and then distilled for use.

\subsection{Synthesis}

\subsubsection{Synthesis of Block Copolymer mPEG-b-PCL-b-mPEG}

The synthesis of the triblock copolymer $m$ PEG- $b$-PCL- $b$ - $m$ PEG used the method of ring-opening polymerization (ROP). The specific operations were appropriate amount of $m \mathrm{PEG}$, and a certain molar ratio of $\alpha$-Chloro- $\varepsilon$-caprolactone $(\alpha \mathrm{Cl} \varepsilon \mathrm{CL})$ and $\varepsilon$-Caprolactone $(\varepsilon \mathrm{CL})$ were taken in a completely dry three-necked flask and dissolved in toluene under a stirring bar. Three drops of catalyst stannous 
octoate were added to the system, the reaction was heated at $120^{\circ} \mathrm{C}$ in an oil bath under the protection of nitrogen atmosphere. After moderate stirring for $12 \mathrm{~h}$, the reaction system was cooled to $60^{\circ} \mathrm{C}$. Hexamethylene diisocyanate (HMDI) was added into the mixture and reacted with the diblock copolymer $m$ PEG- $b$-PCL in a ratio of 1:2 for another $6 \mathrm{~h}$. Then, the reaction system was cooled to room temperature. Isolated the product by precipitated in cold methanol, then dissolved in dichloromethane, and isolated by precipitated in cold diethyl ether again. The $\alpha$-chloro- $\varepsilon$-caprolactone used in this step was synthesized according to the method of the literature [35]. ${ }^{1} \mathrm{H} N M R\left(\mathrm{CDCl}_{3}\right): \delta-1.68(\mathrm{~m}, 3 \mathrm{H}), \delta-2.01$ $(\mathrm{m}, 3 \mathrm{H}), \delta-4.13\left(\mathrm{~m}, 1 \mathrm{H}, \mathrm{COOCH}_{2}\right), \delta-4.53\left(\mathrm{~m}, 1 \mathrm{H}, \mathrm{COOCH}_{2}\right), \delta-4.74(\mathrm{dd}, 1 \mathrm{H}, \mathrm{CHCl})$.

2.2.2. Synthesis of mPEG-b-[PCL-g-(MEO $\left.\left.{ }_{2} \mathrm{MA}-\mathrm{co}-\mathrm{OEGMA}\right)\right]-\mathrm{b}-\mathrm{mPEG}$ and Azide End-Functionalized mPEG-b-[PCL-g-( $\mathrm{MEO}_{2}$ MA-co-OEGMA)]-b-mPEG

The block-graft copolymer $m$ PEG- $b$-[PCL- $g$-(MEO ${ }_{2} \mathrm{MA}-c o$-OEGMA)]- $b-m$ PEG was synthesized by the method of atom transfer radical polymerization (ATRP), and the specific operations were as follows; the triblock copolymer $m$ PEG- $b$-PCL- $b$ - $m$ PEG $(412.60 \mathrm{mg}, 0.10 \mathrm{mmol})$ was taken in a dry schlenk flask under the protection of nitrogen atmosphere. When the copolymer was completely dissolved in $5.00 \mathrm{~mL} \mathrm{~N}, N$-dimethylformamide, $\mathrm{MEO}_{2} \mathrm{MA}(1.80 \mathrm{~mL}, 9.70 \mathrm{mmol})$ and OEGMA $(0.13 \mathrm{~mL}$, $0.30 \mathrm{mmol}$ ) were added to reaction system with moderated stirring. The freeze-pump-thaw operation was repeated three times in order to remove oxygen. Then, the catalyst of cuprous chloride $(10.30 \mathrm{mg}$, $0.10 \mathrm{mmol})$ and $2,2^{\prime}$-bipyridine $(31.50 \mathrm{mg}, 0.20 \mathrm{mmol})$ was added to schlenk flask. The schlenk flask was sealed and heated in an oil bath at $70{ }^{\circ} \mathrm{C}$. After $12 \mathrm{~h}$, the system was stopped and cooled to room temperature. The viscous product was diluted with deionized water and transferred to MWCO14kDa dialysis bags for 3 days to remove impurities. After freeze-drying, the transparent colloidal $m$ PEG- $b$-[PCL- $g$-(MEO ${ }_{2}$ MA-co-OEGMA)]- $b$ - $m$ PEG was obtained.

$m$ PEG- $b$-[PCL- $g$-(MEO ${ }_{2}$ MA-co-OEGMA)]- $b$ - $m$ PEG $(330.00 \mathrm{mg})$ and sodium azide $(37.00 \mathrm{mg})$ were

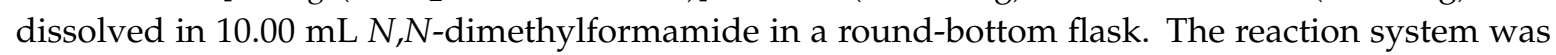
stirred at room temperature for $72 \mathrm{~h}$. The product was isolated by precipitated in anhydrous diethyl ether. After dilution with water, the product was transferred toMWCO14kDa dialys is bags for dialysis. Last, after freeze-drying to remove the water, a slightly white colloidal product azide end-functionalized copolymer $m$ PEG- $b$-[PCL- $g$-(MEO ${ }_{2}$ MA-co-OEGMA)]- $b$ - $m$ PEG was obtained.

\subsubsection{Synthesis of Cross-Linker Alkyne-Terminated P(GMA-co-MEO ${ }_{2} \mathrm{MA}-$-co-OEGMA)}

$\mathrm{P}\left(\mathrm{GMA}-\mathrm{co}-\mathrm{MEO}_{2} \mathrm{MA}-\mathrm{co}\right.$-OEGMA) was synthesized by the reversible addition-fragmentation chain transfer polymerization (RAFT) method. First, the chain transfer agent CTA was synthesized according to the method in the literature [36]. CTA $(36.40 \mathrm{mg}, 0.10 \mathrm{mmol}), \mathrm{MEO}_{2} \mathrm{MA}(2.50 \mathrm{~mL}$, $13.58 \mathrm{mmol})$, OEGMA $(0.18 \mathrm{~mL}, 0.42 \mathrm{mmol})$ and GMA $(0.08 \mathrm{~mL}, 0.60 \mathrm{mmol})$ were dissolved in $5.00 \mathrm{~mL}$ 1,4-dioxane in a dry schlenk flask under the protection of nitrogen atmosphere. The schlenk flask was placed in an ice water bath below $10^{\circ} \mathrm{C}$ with moderated stirring for $40 \mathrm{~min}$. Then, $20.00 \mathrm{mg}$ AIBN was added to the reaction system. The schlenk flask was replaced in a $60^{\circ} \mathrm{C}$ oil bath. $5 \mathrm{~h}$ later, the reaction system was cooled to room temperature. The product was diluted with deionized water, and then transferred to MWCO14kDa dialysis bags for dialysis. After freeze-drying to remove the water, a pale yellow product was obtained.

The above $\mathrm{P}\left(\mathrm{GMA}-\mathrm{co}-\mathrm{MEO}_{2} \mathrm{MA}-\mathrm{co}\right.$-OEGMA) $(574.00 \mathrm{mg})$ and $\mathrm{NaH}(46.00 \mathrm{mg}$ ) were completely dissolved in tetrahydrofuran (THF) in a dry $10.00 \mathrm{~mL}$ round-bottom flask, and stirred moderately for $15 \mathrm{~min}$. Then, propargyl bromide $(0.17 \mathrm{~mL})$ was added to the reaction system. The reaction was carried out at room temperature for $48 \mathrm{~h}$, and then the product was transferred to an MWCO14kDa dialysis bags for 3 days. After freeze-drying to remove the water, the yellow product alkyne-terminated $\mathrm{P}\left(\mathrm{GMA}-\mathrm{co}-\mathrm{MEO}_{2} \mathrm{MA}-\mathrm{co}\right.$-OEGMA) was obtained. 


\subsubsection{Synthesis of Cross-Linker TPOM}

TPOM was synthesized according to the methods provided in the previous literature [34]. The specific procedure was $\mathrm{KOH}(15.60 \mathrm{~g})$ and pentaerythritol $(2.50 \mathrm{~g})$ were dissolved in $30.00 \mathrm{~mL}$ of $\mathrm{N}$, $\mathrm{N}$-dimethylformamide in a dry $100.00 \mathrm{~mL}$ round-bottom flask. The mixture system was stirred at $5{ }^{\circ} \mathrm{C}$ for $30 \mathrm{~min}$. Then, the propargyl bromide ( $20.80 \mathrm{~g}$ ) was added dropwise into the reaction over $20 \mathrm{~min}$. The mixture became brown, and reacted at $40{ }^{\circ} \mathrm{C}$ for $24 \mathrm{~h}$. After cooling, an appropriate amount of water was added to stop the reaction, and the mixture was extracted with $50.00 \mathrm{~mL}$ diethyl ether. The organic layers were combined, and washed with brine and water, and then dried over $\mathrm{MgSO}_{4}$. Finally, the crude product was purified by the silica gel column, which using ethyl acetate-hexane $(V / V=2: 8)$ as a mobile phase, giving an orange pure product.

\subsubsection{Preparation of Two Hydrogels via Click Chemistry}

The azide end-function $m$ PEG- $b$-[PCL- $g$-( $\left(\mathrm{MEO}_{2} \mathrm{MA}-c o\right.$-OEGMA)]- $b$ - $m$ PEG and the alkyne -terminated $\mathrm{P}\left(\mathrm{GMA}-\mathrm{co}-\mathrm{MEO}_{2} \mathrm{MA}-\mathrm{co}\right.$-OEGMA) in a certain molar ratio were dissolved in the deionized water, and the system was stirred. After the solution turned clear, sodium ascorbate $(0.15 \mathrm{~g})$ and a few drops saturated copper sulfate pentahydrate solution were added to mixture quickly. Gels appeared within $1 \mathrm{~min}$. The reaction was continued until present a homogeneous solid structure gels at room temperature. The gels were rinsed with deionized water for several times to remove unreacted impurities.

The azide end-functionalized $m$ PEG- $b$-[PCL- $g$-( $\left.\left.\mathrm{MEO}_{2} \mathrm{MA}-c o-\mathrm{OEGMA}\right)\right]-b-m \mathrm{PEG}$ and the tetrakis (2-propynyloxymethyl)-methane (TPOM) were dissolved in $N, N$-dimethylformamide (DMF) in a dry $10.00 \mathrm{~mL}$ round-bottom flask. Then, the $N, N, N^{\prime}, N^{\prime}, N^{\prime \prime}$-pentamethyl diethylenetriamine (PMDETA) $(17.40 \mathrm{mg})$ was added to the reaction system with moderate stirring. When the solution was clear, $\mathrm{CuCl}$ $(7.20 \mathrm{mg})$ was added into the round-bottom flask quickly. Gels appeared within $1 \mathrm{~min}$. The reaction was continued to react at room temperature for $24 \mathrm{~h}$.

\subsection{Characterization}

\subsubsection{Nuclear Magnetic Resonance Spectroscopy $\left({ }^{1} \mathrm{H}\right.$ NMR)}

The chemical structures of some copolymers synthesized in this work were analyzed by ${ }^{1} \mathrm{H}$ NMR in $\mathrm{CDCl}_{3}$ using a Bruker $300 \mathrm{MHz}$ spectrometer $\left({ }^{1} \mathrm{H}\right.$ NMR) (300 MHz AVANCE, Bruker Corporation, Karlsruhe, Germany) at room temperature. The chemical shifts are given relative to tetramethylsilane (TMS).

\subsubsection{Fourier-transform infrared Spectroscopy (FTIR)}

The infrared spectrums of some copolymers were measured on a Bruker FTIR (Tensor 27, Bruker Corporation, Karlsruhe, Germany). Before being measured, the dried sample should be mixed with $\mathrm{KBr}$, ground into a powder. and tableted.

\subsubsection{Gel Permeation Chromatography (GPC)}

The number average molecular weight $\left(M_{n}\right)$, polydispersity index $\left(M_{\mathrm{W}} / M_{\mathrm{n}}\right)$, and molecular weight distribution (PDI) of the copolymers were recorded by gel permeation chromatography (GPC) (Breeze, Water, Milford, MA, USA). In method, tetrahydrofuran is both mobile phase and solvent, and a series of different molecular weight PEG aqueous $\left(2 \mathrm{mg} \cdot \mathrm{mL}^{-1}\right)$ were prepared as standard samples. Then test the copolymer's GPC trace and determine the $M_{\mathrm{n}}, M_{\mathrm{W}}$, and PDI. All of the sample aqueous in above were filtered with a $0.25-\mu \mathrm{m}$ oil phase filter before being measured.

\subsection{Water Solubility and Temperature Sensitivitys}

The water solubility and temperature sensitivity were predetermined by taking digital photos of the copolymer aqueous $(2.00 \mathrm{mg} / \mathrm{mL})$ in a transparent glass vial at 25,35 and $45^{\circ} \mathrm{C}$ respectively. 
In addition, the water solubility and temperature sensitivity of the block-graft copolymers were illustrated by the transmittance measured with a UV-Vis spectroscopy (TU-1901, Beijing Purkinje General Instrument Corporation, Beijing, China).The transmittance of a series copolymers aqueous $(2.00 \mathrm{mg} / \mathrm{mL})$ was measured by UV-Vis spectrophotometer at different temperature, and then the correlation curve was drawn according to the transmittance change with temperature; the inflection points of the curve is the low critical solution temperature (LCST) of the different component block-graft copolymers. We configured the solutions at $0.50,1.00,2.00,4.00$, and $8.00 \mathrm{mg} / \mathrm{mL}$ tBG4 aqueous solutions, respectively, and then the transmittance change of the different solutions from 25 to $50{ }^{\circ} \mathrm{C}$ was measured to obtain the low critical solution temperature (LCST).

\subsection{Micelle Properties of Polymers}

Determination of critical micelle concentration (CMC): (1) Surface tension is one of the methods to determine the critical micelle concentration value of the copolymers. This experiment measured the surface tension of the copolymer solutions with the surface tension meter (DCAT21, Germany Dataphysics Corporation, Stuttgart, Germany). (2) Fluorescent probe technology is another way to determination the critical micelle concentration. The measurement was performed with a fluorescence spectrophotometer (PELS55, America Perkin Elmer Corporation, Waltham, MA, USA), and used pyrene as a steady-state hydrophobic fluorescent probe. The peak intensities ratios of the third peak $\left(I_{3}, 384 \mathrm{~nm}\right)$ to the first peak $\left(I_{1}, 373 \mathrm{~nm}\right)$ of the emission spectra were recorded, and then plotted as $I_{3} / I_{1}$ ratio and $\log c$ curves; the critical micelle concentration $(\mathrm{CMC})$ value is defined as the turning point of the linear regression lines on plots.

Dynamic light scattering (DLS): The particle size distribution of the block-graft copolymers aqueous was gauged by a dynamic light scattering (DLS) instrument ZS 90 (Otsukaelectronics, Osaka, Japan), which has a $4 \mathrm{~mW}$ He-Nesolid-state laser. Each sample solution $\left(1.00 \mathrm{mg} \cdot \mathrm{mL}^{-1}\right)$ was filtered with a $0.45-\mu \mathrm{m}$ water phase filter before measurement. The laser wavelength was $633 \mathrm{~nm}$, the scattering angle was $90^{\circ}$, and the temperature range was from 25 to $50^{\circ} \mathrm{C}$.

Transmission electron microscopy (TEM): The micelle morphology was observed by JEOL JEM-2100 transmission electron microscopy (Tokey, Japan) with accelerating voltage $200 \mathrm{kV}$. The samples was prepared by placing a drop of $1.00 \mathrm{mg} \cdot \mathrm{mL}^{-1}$ copolymers solution on a carbon-coated copper grid (200 mesh), stained with $1.00 \mathrm{wt} \%$ phosphotungstic acid solution, and then dried in the vacuum at 25 and $35^{\circ} \mathrm{C}$, respectively.

\subsection{Sol-gel Transition}

The gel-to-sol transition of the copolymer solutions was measured by the test vial inverting method. The different mass copolymers were dissolved in water in a vial and stirred for 2 days at room temperature. Then, we placed vials of copolymer solutions in a water bath from $20^{\circ} \mathrm{C}$ to $50^{\circ} \mathrm{C}$ and waited until the solutions were equilibrated at every temperature for $20 \mathrm{~min}$. The vials were inverted for $5 \mathrm{~s}$ to observe the states of these solutions, and the temperature at which the copolymer solutions changed from a flow state to a stationary state was recorded.

\subsection{SEM Analysis of Gel}

The surface morphology of the two hydrogels was taken by an environmental scanning electron microscope (Quanta 200). The gels were immersed in distilled water to swell equilibrium, and then were placed in liquid nitrogen quickly for preserved the gels morphology. When dried by a freeze dryer, the gels' microscopic morphology was measured at a high vacuum mode. In order to increase the conductivity of the sample, the gels were sprayed with gold. 


\section{Results and Discussion}

\subsection{Synthesis of the Copolymers and Hydrogels}

In this study, the triblock-graft copolymers $m$ PEG- $b$-[PCL- $g$-( $\left.\left.\mathrm{MEO}_{2} \mathrm{MA}-c o-\mathrm{OEGMA}\right)\right]-b-m$ PEG were synthesized by the combination of ROP and ATRP. First, the $m$ PEG- $b$-PCL diblock copolymers were synthesized via ROP of $\varepsilon$-Caprolactone and at $120^{\circ} \mathrm{C}$ for $12 \mathrm{~h}$, the $\mathrm{sn}(\mathrm{Oct})_{2}$ was the catalyst. Moreover, the $m$ PEG- $b$-PCL- $b$ - $m$ PEG triblock copolymers were produced by couple the $m$ PEG- $b$-PCL diblock copolymer with HMDI at $60{ }^{\circ} \mathrm{C}$ for $6 \mathrm{~h}$. Then, the $m$ PEG- $b$-[PCL- $g$-(MEO $\left.\left.2 \mathrm{MA}-c o-O E G M A\right)\right]-b-m$ PEG triblock-graft copolymers were synthesized by ATRP and azide triblock-graft copolymer to obtain azide en-functionalized triblock-graft copolymer. Under the premise of the triblock-graft copolymer generated, the cross-linker alkynyl P(GMA-co-MEO $\left.\mathrm{MA}_{2} \mathrm{MA}-\mathrm{co}-\mathrm{OEGMA}\right)$ was produced by RAFT, and another cross-linker agent TPOM was synthesized by organic reaction. Finally, the azide end-functionalized triblock-graft copolymers were reacted with the two cross-linkers via click chemistry separately, obtained two hydrogels under different conditions. As shown in Scheme 1.

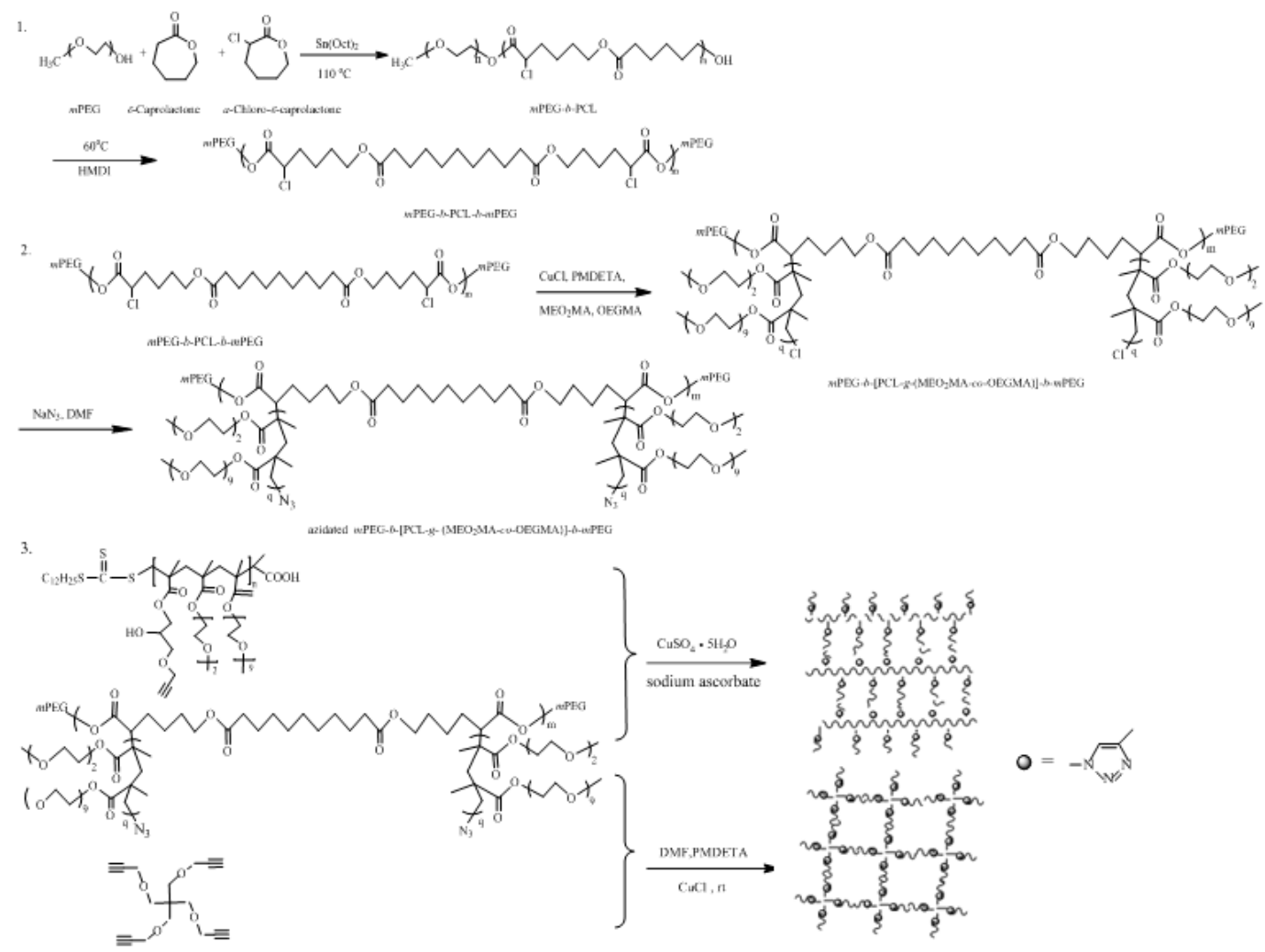

Scheme 1. Synthesis route of copolymers and two hydrogels.

Figures S1-S4 represent the infrared spectra spectrum and nuclear magnetic spectrum of the copolymers; the absorption peak or vibration peak of the special functional group has been marked.

Figure S5 shows the infrared spectrum of the azide en-functionalized triblock-graft copolymer, the alkyne-terminated P(GMA-co-MEO $2 \mathrm{MA}-\mathrm{co}-\mathrm{OEGMA})$, the TPOM, and the two gels. Figure S5a, as with Figure $S 2 b$, is the infrared spectrum of the azide en-functionalized triblock-graft copolymer. Figure S5b represents the alkyne-terminated $\mathrm{P}\left(\mathrm{GMA}-\mathrm{co}-\mathrm{MEO}_{2} \mathrm{MA}-\mathrm{co}-\mathrm{OEGMA}\right)$. Figure S5c is the infrared spectrum of TPOM, the 2100 and $3280 \mathrm{~cm}^{-1}$ peaks were the shrinkage vibration peaks of $\mathrm{C} \equiv \mathrm{C}$ and $\mathrm{C}-\mathrm{H}$ on $\mathrm{C} \equiv \mathrm{CH}$. Figure $\mathrm{S} 5 \mathrm{~d}$,e represents the infrared spectrum of the two gels, respectively, the infrared spectrum of the gels no longer shows the characteristic functional groups of the reactants of the cross-linkers, indicating that the azide en-functionalized triblock-graft copolymer reacts well with both cross-linkers. 


\subsection{GPC Characterization of the Copolymers}

In the step of $m$ PEG- $b$-PCL- $b$ - $m$ PEG triblock copolymer synthesis, the total amount of $\varepsilon$-Caprolactone and $\alpha$-Chloro- $\varepsilon$-Caprolactone added to the reaction remained unchanged, while the ratios of the $\varepsilon$-Caprolactone and the $\alpha$-Chloro- $\varepsilon$-Caprolactone were 8:2, 7:3, 6:4, and 5:5, respectively. The difference in the content of the characteristic functional group $\mathrm{Cl}$ determines the difference in the total amount of the grafted $\mathrm{MEO}_{2} \mathrm{MA}$ and OEGMA copolymer on the triblock-graft copolymer. Therefore, the molecular weights of the copolymers also were differs. Figure 1 shows the GPC trace of the four polymers. All of the curves are single peaks, and with narrow distribution, indicating that the method used in the experiment is indeed advantageous for the synthesis of copolymers with narrow molecular weight distribution. In addition, with the increase of the theoretical molecular weight of the copolymers, the GPC trace grew gradually broader. This illustrated that the larger the copolymer's molecular weight designed, the more the product distribution dispersed. Detailed information of each copolymer is shown in Table 1.

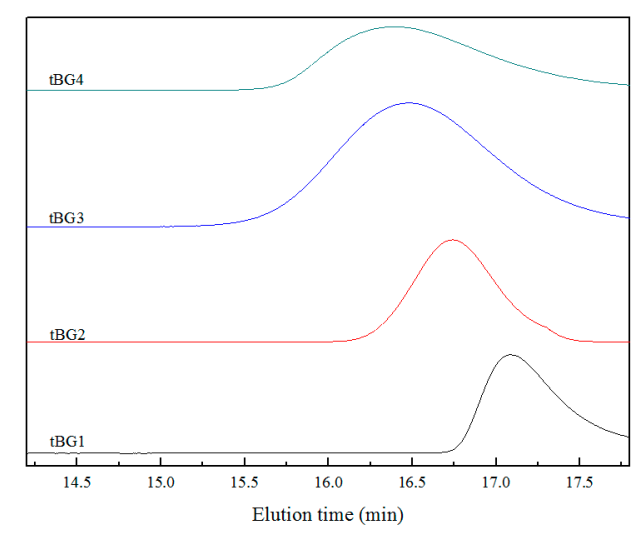

Figure 1. Gel permeation chromatography (GPC) trace of the copolymers.

Table 1. Synthesis data of copolymers.

\begin{tabular}{|c|c|c|c|c|c|c|c|}
\hline Samples & $\begin{array}{c}{\left[\alpha \mathrm{Cl}{ }_{\varepsilon \mathrm{CL}] /[\varepsilon \mathrm{CL}]^{a}}\right.} \\
(n: n)\end{array}$ & $\begin{array}{c}{[\alpha \mathrm{Cl} \varepsilon \mathrm{CL}] /[\mathrm{MO}]^{b}} \\
(n: n)\end{array}$ & $\begin{array}{c}\text { Time } \\
\text { (h) }\end{array}$ & $\begin{array}{c}\text { Conversion } \\
(\%)\end{array}$ & $\begin{array}{c}\text { Mn, Theory } \\
\text { (g/mol) }\end{array}$ & $\begin{array}{c}M n, \text { GPC } \\
(\mathrm{g} / \mathrm{mol})\end{array}$ & PDI \\
\hline $\mathrm{tBG} 1$ & $2: 8$ & $1: 10$ & 12 & 56.8 & 18,988 & 22,469 & 1.06 \\
\hline tBG2 & $3: 7$ & $1: 10$ & 12 & 59.6 & 27,704 & 31,654 & 1.07 \\
\hline tBG3 & $4: 6$ & $1: 10$ & 12 & 61.3 & 36,581 & 40,788 & 1.22 \\
\hline tBG4 & $5: 5$ & $1: 10$ & 2 & 9.8 & 10,625 & 10,023 & 1.05 \\
\hline tBG4 & $5: 5$ & $1: 10$ & 4 & 20.5 & 17,722 & 21,172 & 1.09 \\
\hline tBG4 & $5: 5$ & $1: 10$ & 8 & 37.4 & 28,930 & 30,181 & 1.17 \\
\hline tBG4 & $5: 5$ & $1: 10$ & 12 & 61.5 & 44,914 & 48,131 & 1.24 \\
\hline tBG4 & $5: 5$ & $1: 10$ & 24 & 72.7 & 52,342 & 57,895 & 1.30 \\
\hline tBG4 & $5: 5$ & $1: 10$ & 48 & 78.0 & 55,857 & 60,583 & 1.37 \\
\hline
\end{tabular}

$[\alpha \mathrm{Cl} \varepsilon \mathrm{CL}] /[\varepsilon \mathrm{CL}]^{a}$ is molar ratio of $\alpha$-Chloro- $\varepsilon$-caprolactone $(\alpha \mathrm{Cl} \varepsilon \mathrm{CL})$ and $\varepsilon$-Caprolactone $(\varepsilon \mathrm{CL})$. [MO $]^{b}$ is the initial molar ratio of $\mathrm{MEO}_{2} \mathrm{MA}$ and OEGMA, and the ratio between $\mathrm{MEO}_{2} \mathrm{MA}$ and OEGMA in all block-graft copolymers is 97:3.

\subsection{Relationship between Conversion Rate and Molecular Weight}

As can be seen from the Table 1 and Figure 2a, the conversion rate of the copolymers increased progressively with reaction time. When the reaction time is less than $12 \mathrm{~h}$, the conversion rate increases rapidly, while the reaction conversion rate increases slowly after $12 \mathrm{~h}$. In addition, the effect of conversion on Mn and PDI has been shown in Figure 2b, and, as can be seen from the figure, the molecular weight of the copolymer increases continuously with the increases of reaction conversion, and the PDI of the copolymer is also increases at the same time. 

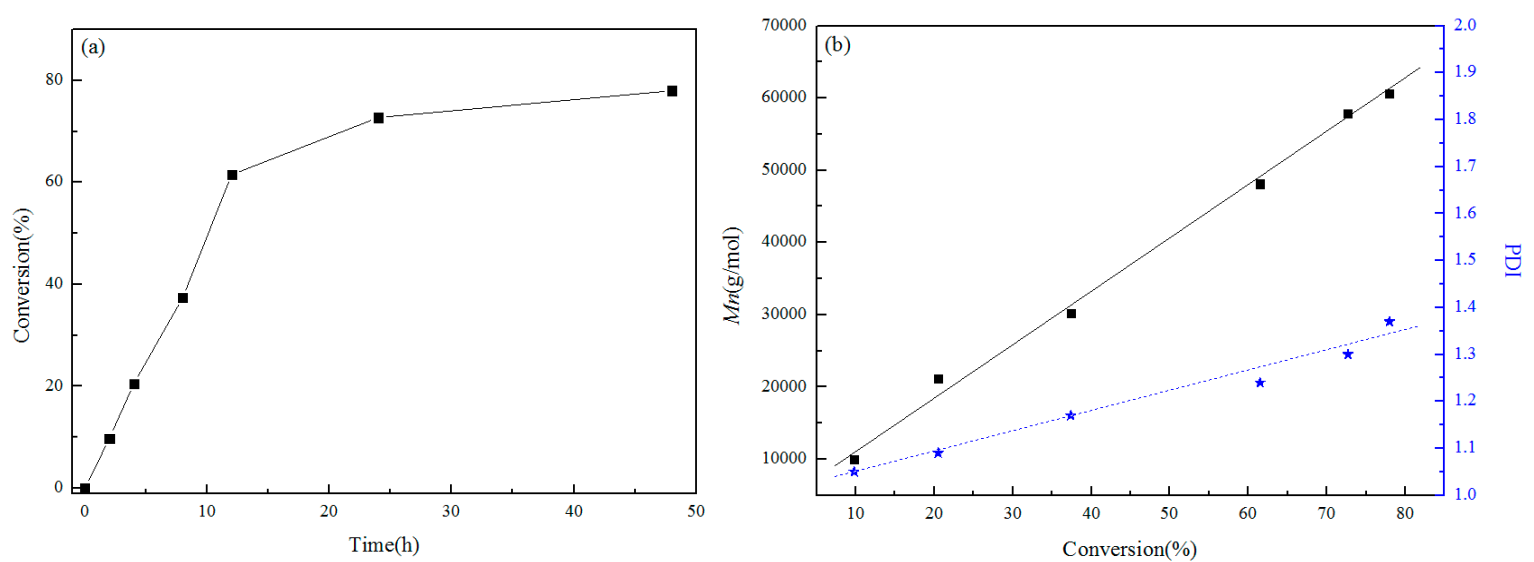

Figure 2. Effect of reaction time on conversion rate (a) and effect of conversion on Mn and PDI (b).

\subsection{Water Solubility and Temperature Sensitivity}

The hydrophilic $m$ PEG segment of the triblock copolymers $m$ PEG- $b$-PCL- $b$ - $m$ PEG was limited, and the hydrophobic PCL chain determined that the water solubility of the copolymer was relatively poor [30]. Once the triblock copolymer $m$ PEG- $b$-PCL- $b$ - $m$ PEG was added to deionized water, the solution became cloudy. While the $\mathrm{P}\left(\mathrm{MEO}_{2} \mathrm{MA}-\mathrm{co}\right.$-OEGMA) graft chains have improved the water solubility of the $m$ PEG- $b$-[PCL- $g$-(MEO $\left.\left.{ }_{2} \mathrm{MA}-c o-\mathrm{OEGMA}\right)\right]-b$ - $m$ PEG triblock-graft copolymers. This is because the hydrophilic oligo(ethylene glycol) graft chain on the copolymers formed hydrogen bonds with water molecules at room temperature. In addition, the PEG analog copolymers formed by the $\mathrm{MEO}_{2} \mathrm{MA}$ and OEGMA have unique temperature sensitivity. Therefore, these two segments make the copolymer have temperature sensitivity [31]. Figure 3 is the photographs of the triblock-graft copolymers (tBG) solutions at 25,35 and $45{ }^{\circ} \mathrm{C}$. The tBGs solutions were clear at $25^{\circ} \mathrm{C}$, while gradually cloudy with temperature rise.

The LCST of copolymers were with a UV-Vis spectroscopy. As shown in Figure 4a, the transmittance from tBG1 to tBG4 was gradually increased at room temperature, which was because the amount of the characteristic functional group $\mathrm{Cl}$ was increased, in other words, the density of the hydrophilic copolymer $\mathrm{P}\left(\mathrm{MEO}_{2} \mathrm{MA}-\mathrm{co}\right.$-OEGMA) segment gradually increases from the tBG1 to tBG4. In addition, as can be seen from the figure, the transmittance of the four copolymer aqueous solutions began to decrease sharply after $35^{\circ} \mathrm{C}$, indicating that the LCST of the tBGs solutions was $\sim 35^{\circ} \mathrm{C}$. Beyond $40{ }^{\circ} \mathrm{C}$, the transmittance of tBG1 became steady, but the others solutions' transmittance was $0 \%$, this illustrated that the content of $\mathrm{MEO}_{2} \mathrm{MA}$ and OEGMA was one of the important factor that affect the temperature sensitivity of the copolymer solutions at the same concentration.

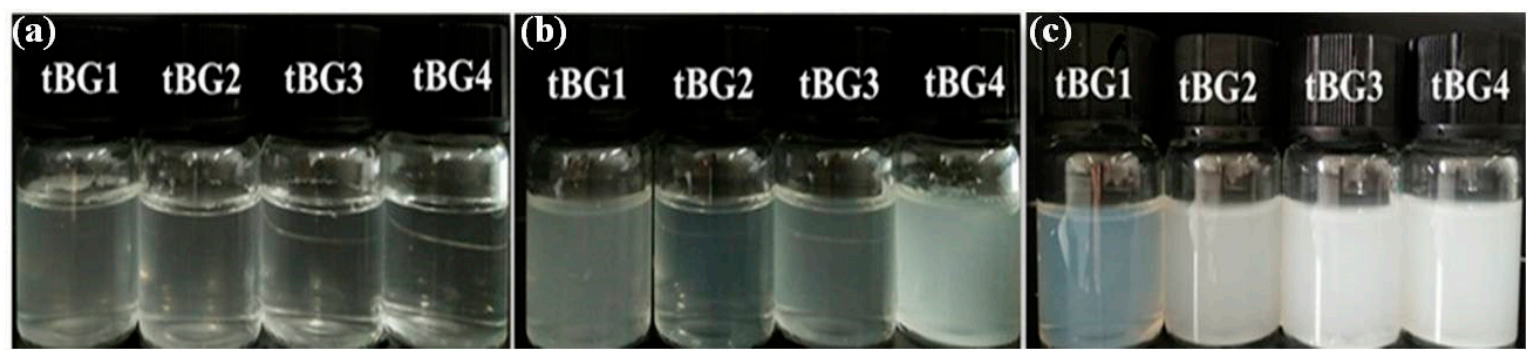

Figure 3. Photographs of the triblock-graft copolymers solutions $(2.00 \mathrm{mg} / \mathrm{mL})$ at $25^{\circ} \mathrm{C}(\mathbf{a}), 35^{\circ} \mathrm{C}(\mathbf{b})$, and $45^{\circ} \mathrm{C}$ (c). 
Figure $4 \mathrm{~b}$ is a graph showing the effect of temperature on tBG4 solutions transmittance with different concentration, and Figure $4 \mathrm{c}$ is the LCST curve of the tBG4 solutions with different concentration. Combining the two graphs, it can be seen that the LCST of the tBG4 copolymer solutions gradually decreases as the concentration increases from 0.50 to $8.00 \mathrm{mg} / \mathrm{mL}$. This indicated that solution concentration was also an important influence factor when studying copolymer solutions; a similar conclusion has been reported before [37].

\subsection{Critical Micellization Concentration Determination (CMC)}

The copolymer molecules are present in a single molecule state when the amphiphilic copolymer solution concentration is very low. Until the concentration increases to a certain value, the copolymer molecules self-assemble into nanoscale core-shell micelles, so this certain concentration value is the critical micelle concentration of the copolymer solution. There are many methods to determine critical micelle concentration. In this study, two experimental methods were used to search the critical micelle concentration: a fluorescence spectrometer and a surface tension meter.

Figure $5 \mathrm{a}$ shows that the $\mathrm{CMC}$ of the $\mathrm{tB} 4$ solution was $8.30 \times 10^{-3} \mathrm{mg} / \mathrm{mL}$. Figure $5 \mathrm{~b}$ shows that the CMC of $\mathrm{tBG} 2, \mathrm{tBG} 3$, and $\mathrm{tBG} 4$ solutions were $2.37 \times 10^{-2}, 5.99 \times 10^{-2}$, and $8.41 \times 10^{-2} \mathrm{mg} / \mathrm{mL}$, respectively, and these values were Three to ten times greater than the $\mathrm{CMC}$ value of the tB4 solution. This explains the CMC value of the block-graft copolymer increases as the $\mathrm{P}\left(\mathrm{MEO}_{2} \mathrm{MA}-\mathrm{co}\right.$-OEGMA $)$ chain. Because the $\mathrm{CMC}$ value of the amphiphilic block-graft copolymer aqueous depends on the length of the hydrophilicity and hydrophobic block, that is, the more of the hydrophilic chain $\mathrm{P}\left(\mathrm{MEO}_{2} \mathrm{MA}\right.$-co-OEGMA $)$ added, the larger the CMC value of the block-graft copolymer when aqueous $[38,39]$.
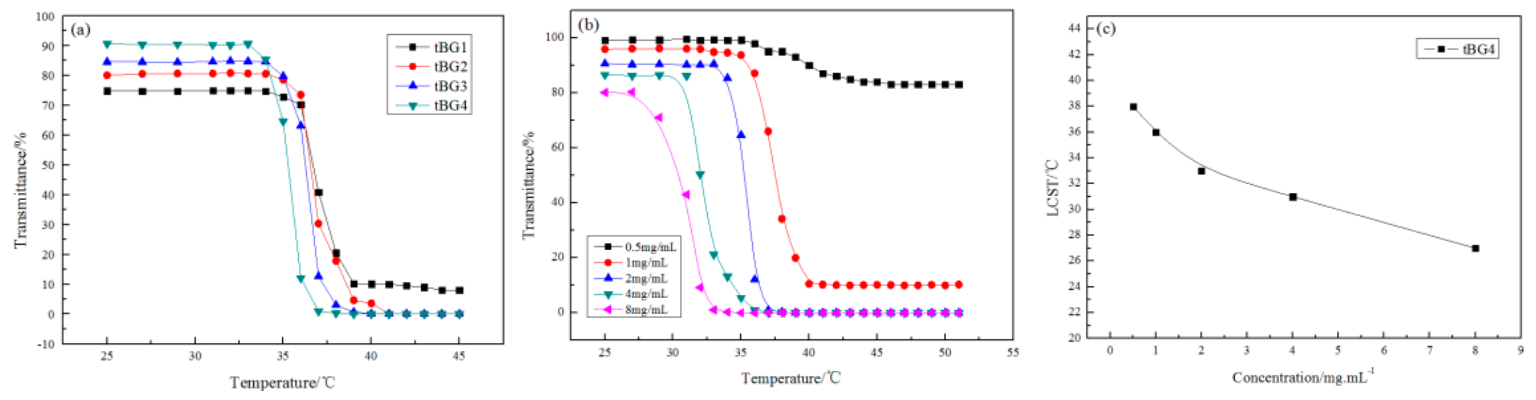

Figure 4. Transmittance tBG1-tBG4 in aqueous solution (a), the transmittance with different concentration tBG4 aqueous solution (b), and the low critical solution temperature (LCST) curve with different concentration of the tBG4 aqueous solution (c).

Figure $5 \mathrm{c}$ is a graph showing the surface tension at different concentrations of $\mathrm{tBG} 2, \mathrm{tBG}$, and tBG4 copolymers solutions measured by the surface tension method, and the turning point is the CMC values of the copolymers. Before the turning point, the surface tension value decreases rapidly with the increase of the solution concentration. At the turning point, the block-graft copolymer self-assembly forms core-shell micelles in the solution. After the turning point, the surface tension hardly changes with the increase of the solution concentration. The results measured by this method are close to the $\mathrm{CMC}$ value measured by the fluorescent probe, and the $\mathrm{CMC}$ value is gradually increasing from the tBG2-tBG4 solution under the same conditions. It also demonstrates that under certain conditions, the better hydrophilicity of the copolymer is the larger CMC is. 

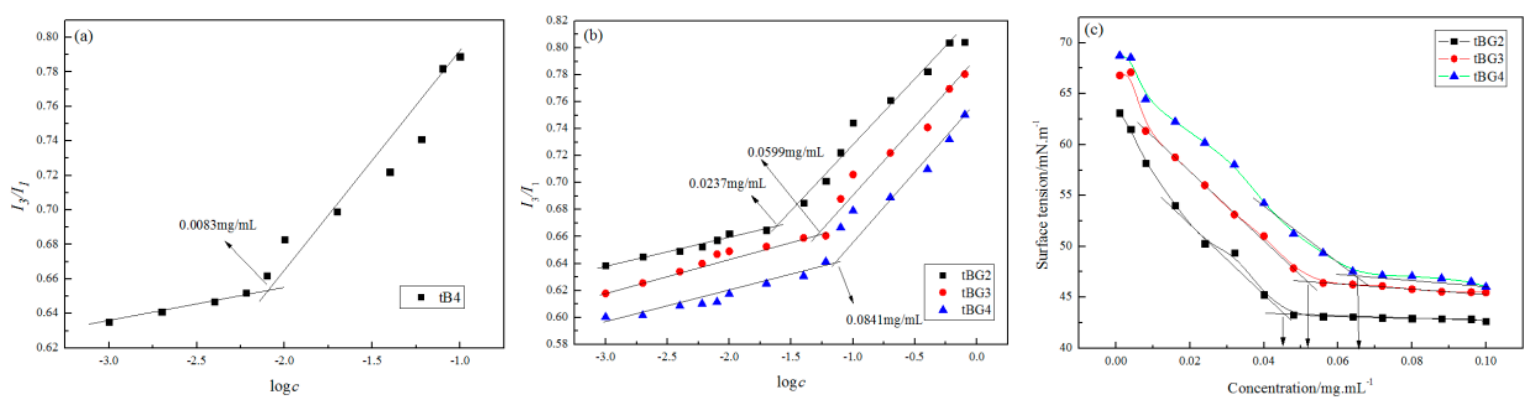

Figure 5. The critical micelle concentration (CMC) of the copolymer tB4 (a); the CMC of copolymer tBG2, tBG3, and tBG4 measured by fluorescence spectrometer (b); and the CMC of copolymers tBG2, tBG3 and tBG4 measured by the surface tension method (c).

\subsection{Particle Size of Copolymer Micelles}

Figure 6a is a graph showing the copolymers' particle size distribution measured by the dynamic light scattering instrument at room temperature. It can be seen from the figure that the particle size of the tBG1-tBG4 copolymers are centralized at $60-70 \mathrm{~nm}$ under the same conditions. At the same time, the micelle particle size distribution range expands slightly from tBG1 to tBG4, which is because the density of the graft chain $\mathrm{P}\left(\mathrm{MEO}_{2} \mathrm{MA}-\mathrm{co}-\mathrm{OEGMA}\right)$ was increased. Theoretically, the more the $\mathrm{P}\left(\mathrm{MEO}_{2} \mathrm{MA}\right.$-co-OEGMA) chains in the block-graft copolymer, the stronger the interaction of the hydrophilic groups at the shell portion of the micelles, so the micelle size should smaller too. The result of the graph is probably due to unevenness in the particle size of the micelles that is produced during the synthesis [40].

Figure $6 \mathrm{~b}$ shows the particle size distribution of the tBG4 copolymer micelles at 25 and $37^{\circ} \mathrm{C}$. It can be seen that the particle size of the micelles is mainly distributed around $60 \mathrm{~nm}$ at $25^{\circ} \mathrm{C}$, while increases to about $200 \mathrm{~nm}$ when temperature arrival to $37^{\circ} \mathrm{C}$. This was because the tBG4 block-graft copolymer self-assembles into a core-shell micelle in aqueous solution at $25^{\circ} \mathrm{C}$, and the temperature responsive graft chain $\mathrm{P}\left(\mathrm{MEO}_{2} \mathrm{MA}-\mathrm{co}\right.$-OEGMA) segments formed hydrogen bonds with water molecules, all of the hydrophilic chains existed with an extended state, so the micelles are present in the solution with a stable structure. But, when the temperature is increased to $37^{\circ} \mathrm{C}$, the hydrogen bonds between the graft chain $\mathrm{P}\left(\mathrm{MEO}_{2} \mathrm{MA}-\mathrm{co}\right.$-OEGMA $)$ and the water molecules become weaker [41], the $\mathrm{P}\left(\mathrm{MEO}_{2} \mathrm{MA}-\mathrm{co}\right.$-OEGMA) chain collapses outside the micelles in a short time frame, and a large amount of $\mathrm{P}\left(\mathrm{MEO}_{2} \mathrm{MA}-\mathrm{co}\right.$-OEGMA $)$ graft chain adheres to the micelles making the micelles are unstable in solution, which made the micelle aggregates coexist with the larger particle size single micelles. This can be reflected in the increased turbidity of the copolymer solution [33].

Transmission electron microscopy is one of the most common methods for studying the morphology of copolymer micelles. This method can not only clearly observe the morphology of the micelles, but also measure the particle size of the micelles. In order to intuitively show the micelles of the copolymer in aqueous solution, taken tBG4 as an example, measured the transmission electron micrographs of the tBG4 copolymer micelles at 25 and $37^{\circ} \mathrm{C}$, as shown in Figure 6c. The morphology of the micelles can be clearly seen from the figure. According to the water solubility research before, the copolymer aqueous solution was very homogeneous at $25^{\circ} \mathrm{C}$; therefore, the prepared micelles were evenly dispersed on the copper mesh at this temperature. In this situation, the particle diameter of the micelles was about $50 \mathrm{~nm}$. The copolymer aqueous solution began to become cloudy when preheated to $37^{\circ} \mathrm{C}$; this is because the hydrogen bond between the graft chain $\mathrm{P}\left(\mathrm{MEO}_{2} \mathrm{MA}-c o-\mathrm{OEGMA}\right)$ with the water molecules began to be destroyed, the micelles sample prepared in this case can be observed the larger particle size, and the particle diameter were $160 \mathrm{~nm}$, but these micelles no longer had a regular spherical shape, this was probably because some of the micelles were stacked together. Comparing Figure 6a with Figure 6b, it can be found that the particle size of the micelles measured by the dynamic light scattering instrument is slightly larger than the micelles diameter observed by the transmission electron microscope, this is 
because the value of the sample particle size observed by TEM was in a dry state, and the blocks were contracted, while the value of the sample particle size observed by DLS was measured the block-graft copolymers' solutions, in which the copolymer chains were in a stretched state.
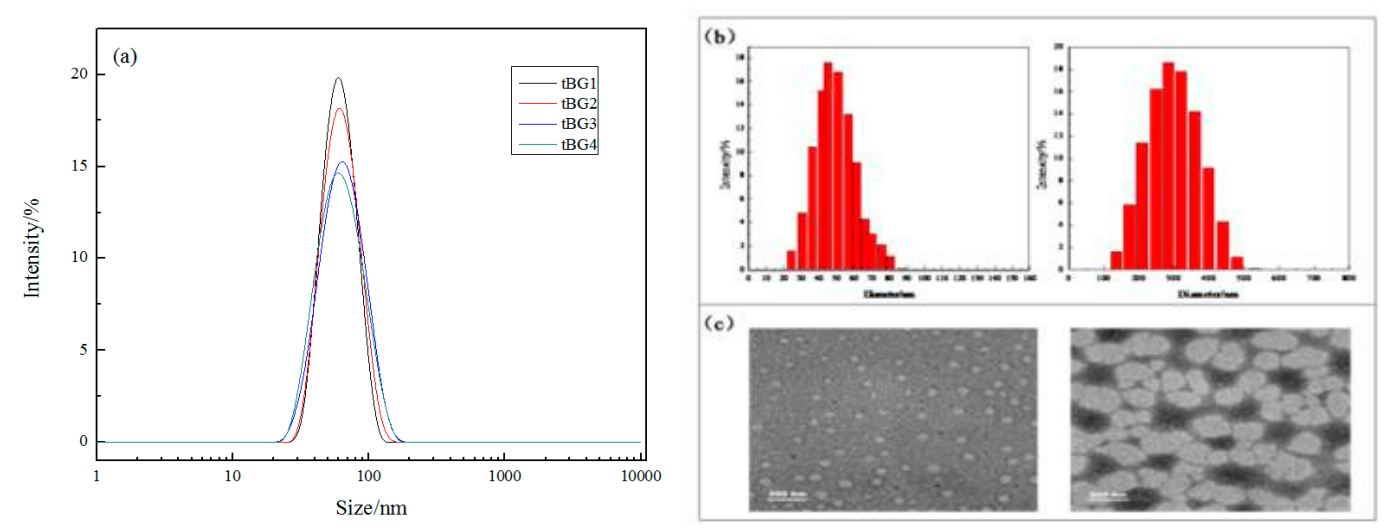

Figure 6. Size distributions of tBGs aqueous solutions (a), measured by DLS at 25 and $37^{\circ} \mathrm{C}(\mathbf{b})$, and TEM images of $\mathrm{tBG} 4$ micelles at 25 and $37^{\circ} \mathrm{C}$ (c).

\subsection{Sol-Gel Transition}

Figure 7a recorded the sol-gel transition of the different concentrations tBG4 copolymer aqueous solutions. Then, we placed all vials of the copolymer solutions in the water bath, until the solution was equilibrated at every temperature. At each temperature, the sample was equilibrated for $15 \mathrm{~min}$, then the vials were inverted for $5 \mathrm{~s}$ to examine whether the copolymer was a flowing liquid or an immobile micelle gel under its own weight [30]. As can be seen from the figure, the sample solutions were still in a flowing state before $25^{\circ} \mathrm{C}$ after the temperature was risen to $30^{\circ} \mathrm{C}$, and copolymer solutions with $25 \%(\mathrm{wt})$ and $20 \%(\mathrm{wt})$ concentration formed a gel and were inverted for $15 \mathrm{~min}$; the gel flow light. Subsequently, the copolymer solutions with $10 \%(\mathrm{wt})$ and $15 \%(\mathrm{wt})$ concentration were also converted into gel at $30{ }^{\circ} \mathrm{C}$, while the two samples were dehydrated directly, and appeared white flocculent substance at $35^{\circ} \mathrm{C}$. As the temperature continues to rise, each component copolymer gel began to dehydrate. This process illustrated that the sol-gel transition temperature of the copolymer aqueous solution was decreases with the increase of the concentration.

Figure $7 \mathrm{~b}$ is the sol-gel transition phase diagram, which was plotted according to the copolymer solution state change at different temperature in order to directly show the relationship between the concentration of the solutions and the sol-gel transition temperature. When the concentration reached a certain level, the amount of micelles in the copolymer aqueous solution was very large, the branches out the core-shell structure of micelles were in contact with each other, and form a plurality of cross-link points which can cross-link to constitute the gel. The greater the concentration of the copolymers solution, the more cross-link points provided, and at the same time, the induced temperature was lower. Continue to increase the temperature after the copolymer solutions transformed into a gel, the graft chains of copolymer micelle collapsed, the dehydration in the core was intensified, the cross-linking point were destroyed. We can see that the collapsed dehydrated micelles were partially viscous, the water was separated out of the micelle, and the copolymer aqueous solution is converted from the gel state to white precipitation.

The sol-gel transition of the copolymer solution based on the cross-linking point, which was formed by the weak interaction between the outer branches of the micelle core; it is a physical cross-linking, so the sol-gel transition process is reversible, the copolymer aqueous solution can achieve a reversible transformation of the sol-gel depending on the temperature rise and fall [42], as shown in Figure 7c. 

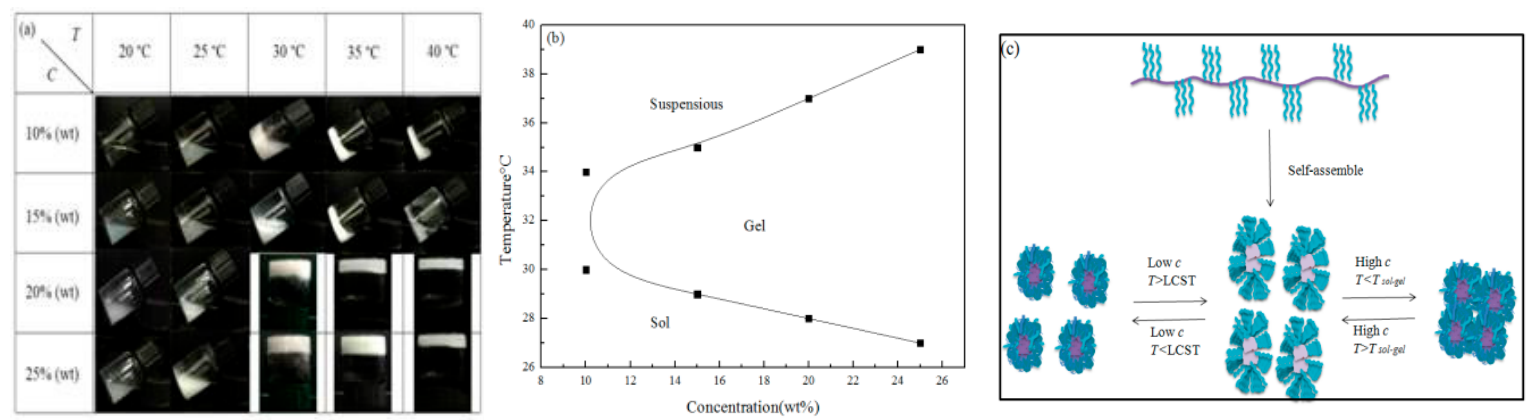

Figure 7. Photographs of the different concentrations tBG4 copolymer aqueous solution at different temperature (a), the sol-gel transition phase diagram of tBG4 (b), and schematic representation of the self-assembled thermo-sensitive core-shell micelles (c).

\subsection{SEM Analysis of Gel}

The morphology of the two dry gels was observed under a scanning electron microscope, as shown in the Figure 8. Both gels have the relatively obvious network structure. Figure 8a,b show the scanned photographs of the gel formed by the azide end-function $m$ PEG- $b$-[PCL- $g$-( $\mathrm{MEO}_{2} \mathrm{MA}-c o$-OEGMA)]-b- $m$ PEG copolymer and the alkyne-terminated $\mathrm{P}\left(\mathrm{MEO}_{2} \mathrm{MA}-c o-\mathrm{OEGMA}\right)$ at 25 and $40{ }^{\circ} \mathrm{C}$, respectively. Figure $8 \mathrm{c}, \mathrm{d}$ show the scanned photographs of the gel formed by the azide end-functionalized copolymer $m$ PEG- $b$-[PCL- $g$-( $\left.\left.\mathrm{MEO}_{2} \mathrm{MA}-c o-\mathrm{OEGMA}\right)\right]-b-m$ PEG with the TPOM at 25 and $40^{\circ} \mathrm{C}$, respectively. Comparing the gel pore sizes in Figure $8 \mathrm{a}-\mathrm{d}$, it was found that the pore size of the first gel was slightly smaller than the second one. This is because the observed porous structure of freeze-dried hydrogels were due to the phase separation of the gels during rapid freezing and subsequent removal of the water by sublimation which left voids in place where the water previously occupied, and the increased cross-link density results in the second gel faster phase separation during freezing [43]. Then, comparing the changes of the two gels between $25^{\circ} \mathrm{C}$ with $40^{\circ} \mathrm{C}$, it can be seen that the gel was in a shrinking state at $40^{\circ} \mathrm{C}$, and the pore size of three-dimensional network become smaller. The reason for this is that the hydrophobic interactions of PCL-PEG chains at a higher temperature ( $T$ > LCST). The SEM images of the hydrogels at different temperature certified that two gels are temperature-sensitive [44].

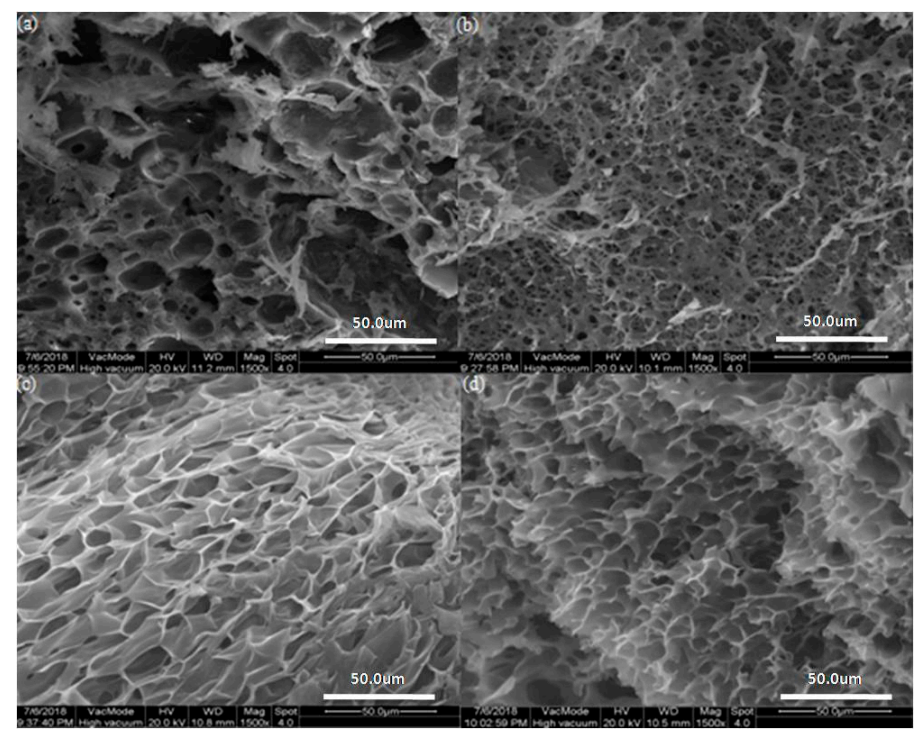

Figure 8. Morphology of gel1 at $25^{\circ} \mathrm{C}(\mathbf{a})$ and $40^{\circ} \mathrm{C}(\mathbf{b})$, and the morphology of gel2 at $25^{\circ} \mathrm{C}(\mathbf{c})$ and $40^{\circ} \mathrm{C}(\mathbf{d})$. 


\section{Conclusions}

The novel hydrogel is composed of the $m$ PEG- $b$-[PCL- $g$-(MEO 2 MA-co-OEGMA)]-b- $m$ PEG block-graft copolymer with the alkynyl $\mathrm{P}\left(\mathrm{GMA}-\mathrm{co}-\mathrm{MEO}_{2} \mathrm{MA}-\mathrm{co}-\mathrm{OEGMA}\right)$ and TPOM via click chemistry. The water-soluble and temperature-sensitive $m$ PEG- $b$-[PCL- - -( $\left(\mathrm{MEO}_{2} \mathrm{MA}-c o\right.$-OEGMA)]- $b$ - $m$ PEG block-graft copolymer was synthesized by ROP and ATRP. The alkynyl P(GMA-co-MEO ${ }_{2}$ MA-co-OEGMA) was synthesized by RAFT and has good water solubility and temperature sensitivity. The LCST of the block-graft copolymer is designed within the normal physiological temperature of the human body. The results of dynamic light scattering and transmission electron microscopy specifically show that the copolymer exist with nanometer size micelles in water, and the state of the micelles can affected by temperature. Sol-gel transition illustrated that the copolymer aqueous solution can achieve a reversible transformation of the sol-gel depending on the temperature rise and fall. After form the gel via click chemistry, the internal three-dimensional network morphology of the gel measured by scanning electron microscopy at different temperatures certified that the hydrogel owned temperature sensitivity. The gels are expected to be used as a material for tissue damage repair. Injecting it with a mixture of growth factors into the human body in-situ click to form a chemical gel can alleviate the pain of surgery.

Supplementary Materials: The following are available online at http://www.mdpi.com/2073-4360/11/5/765/s1. Figure S1: ${ }^{1} \mathrm{HNMR}$ spectra of $m$ PEG- $b$-PCL- $b-m$ PEG triblock copolymer and $m$ PEG- $b$-[PCL- $g$-(MEO 2 MA-co-OEGMA)]-b-Mpeg triblock-graft copolymer, Figure S2: FT-IR spectra of $m$ PEG-b-[PCL-g-(MEO 2 MA-co-OEGMA)]-b- $m$ PEG triblock-graft copolymer and azide end-function alized $m$ PEG- $b$-[PCL- $g$-( $\left(\mathrm{MEO}_{2} \mathrm{MA}-c o\right.$-OEGMA-b- $m$ PEG triblock-graft copolymer, Figure S3: ${ }^{1} \mathrm{HNMR}$ spectra of CTA and P(GMA-co-MEO ${ }_{2}$ MA-co-OEGMA), Figure S4: FT-IR spectra of P(GMA-co-MEO ${ }_{2}$ MA-co-OEGMA) and alkynylated P(GMA-co-MEO ${ }_{2} \mathrm{MA}-c o$-OEGMA), Figure S5: FT-IR spectra of the azidized block-graft copolymer, the cross-linker alkynylation P(GMA-co- $\mathrm{MEO}_{2}$ MA-co-OEGMA), the cross-linker TPOM and the two gels, Table S1: Characterization of various copolymers.

Author Contributions: S.L. and P.S. conceived and designed the experiments; P.S., J.W., X.S., Z.W., and F.S. performed the experiments and analyzed the data; and P.S. and S.L. provided additional intellectual insight and prepared the manuscript.

Acknowledgments: This research was supported by the National Natural Science Foundation of China (No. 21773147) and the Natural Science Foundation of Shaanxi Province of China (No. 2016JM2003).

Conflicts of Interest: The authors declare no conflicts of interest.

\section{References}

1. Yuan, Y.; Zhang, A.K.; Ling, J.; Yin, L.H.; Chen, Y.; Fu, G.D. Well-defined biodegradable amphiphilic conetworks. Soft Matter 2013, 9, 6309-6318. [CrossRef]

2. Li, L.; Lu, B.B.; Wu, J.N.; Fan, Q.K.; Guo, X.H.; Liu, Z.Y. Synthesis and self-assembly behavior of thermo-responsive star-shaped POSS-(PCL- P(MEO ${ }_{2} \mathrm{MA}-\mathrm{co}$-PEGMA) $)_{16}$ inorganic/organic hybrid block copolymers with tunable lower critical solution temperature. New J. Chem. 2016, 40, 4761-4768. [CrossRef]

3. Han, Y.; Li, Y.H.; Zeng, Q.Y.; Li, H.Y.; Peng, J.L.; Xu, Y.H.; Chang, J. Injectable bioactive akermanite/alginate composite hydrogels for in situ skin tissue engineering. J. Mater. Chem. B 2017, 5, 3315-3326. [CrossRef]

4. Döring, A.; Birnbaum, W.G.; Kuckling, D. Responsive hydrogels-structurally and dimensionally optimized smart frameworks for applications in catalysis, micro-system technology and material science. Chem. Soc. Rev. 2013, 42, 7391-7420. [CrossRef] [PubMed]

5. Lin, G.Y.; Cosimbescu, L.; Karin, N.J.; Gutowska, A.; Tarasevich, B.J. Injectable and thermogelling hydrogels of PCL-g-PEG: Mechanisms, rheological and enzymatic degradation properties. J. Mater. Chem. B 2013, 1, 1249-1255. [CrossRef]

6. Qian, S.S.; Zhou, C.; Xu, L.Q.; Yao, F.; Cen, L.; Fu, G.D. High strength biocompatible PEG single-network hydrogels. RSC Adv. 2014, 4, 25241-25250. [CrossRef]

7. Kabir, M.H.; Hazama, T.; Watanabe, Y.; Gong, J.; Murase, K.; Suanda, T.; Furukawa, H. Smart hydrogel with shape memory for biomedical applications. J. Taiwan Inst. Chem. Eng. 2014, 45, 3134-3138. [CrossRef]

8. Lim, H.L.; Hwang, Y.S.; Kar, M.; Varghese, S. Smart hydrogels as functional biomimetic systems. Biomater. Sci. 2014, 2, 603-618. [CrossRef] 
9. Yu, L.; Ding, J.D. Injectable hydrogels as unique biomedical materials. Chem. Soc. Rev. 2008, 37, $1473-1481$. [CrossRef]

10. Ravichandran, R.; Astrand, C.; Patra, H.K.; Turner, A.P.F.; Chotteau, V.; Phopase, J. Intelligent ECM mimetic injectable scaffolds based on functional collagen building blocks for tissue engineering and biomedical applications. RSC Adv. 2017, 7, 21068-21078. [CrossRef]

11. Che, Y.J.; Li, D.P.; Liu, Y.L.; Ma, Q.L.; Tan, Y.B.; Yue, Q.Y.; Meng, F.J. Physically cross-linked pH-responsive chitosan-based hydrogels with enhanced mechanical performance for controlled drug delivery. RSC Adv. 2016, 6, 106035-106045. [CrossRef]

12. Ding, X.C.; Wang, Y.D. Weak bond-based injectable and stimuli responsive hydrogels for biomedical applications. J. Mater. Chem. B 2017, 5, 887-906. [CrossRef]

13. Gong, Z.Y.; Zhang, G.P.; Zeng, X.L.; Li, J.H.; Li, G.; Huang, W.P.; Sun, R.; Wong, C.P. High-strength, tough, fatigue resistant, and self-healing hydrogel based on dual physically cross-linked network. ACS Appl. Mater. Interfaces 2016, 8, 24030-24037. [CrossRef]

14. Kolb, H.C.; Finn, M.G.; Sharpless, K.B. Click chemistry: Diverse chemical function from a few good reactions. Angew. Chem. Int. Ed. 2004, 40, 2004-2021. [CrossRef]

15. Es-haghi, S.S.; Leonov, A.I.; Weiss, R.A. Deconstructing the double-network hydrogels: The importance of grafted chains for achieving toughness. Macromolecules 2014, 47, 4769-4777. [CrossRef]

16. Hemingway, M.G.; Gupta, R.B.; Elton, D.J. Hydrogel nanopowder production by inverse-miniemulsion polymerization and supercritical drying. Ind. Eng. Chem. Res. 2010, 49, 10094-10099. [CrossRef]

17. Malkoch, M.; Vestberg, R.; Gupta, N.; Mespouille, L.; Dubois, P.; Mason, A.F.; Hedrick, J.L.; Liao, Q.; Frank, C.W.; Kingsbury, K.; Hawker, C.J. Synthesis of well-defined hydrogel networks using click chemistry. Chem. Commun. 2006, 2774-2776. [CrossRef]

18. Crescenzi, V.; Cornelio, L.; Meo, C.D.; Nardecchia, S.; Lamanna, R. Novel hydrogels via click chemistry: Synthesis and potential biomedical applications. Biomacromolecules 2007, 8, 1844-1850. [CrossRef] [PubMed]

19. Ossipov, D.A.; Hilborn, J. Poly(vinyl alcohol)-based hydrogels formed by "click chemistry". Macromolecules 2006, 39, 1709-1718. [CrossRef]

20. Grover, G.N.; Lam, J.; Nguyen, T.H.; Segura, T.; Maynard, H.D. Bicompatible hydrogels by oxime click chemistry. Biomacromolecules 2012, 13, 3013-3017. [CrossRef] [PubMed]

21. Meldal, M.; Tornøe, C.W. Cu-catalyzed azide-alkyne cycloaddition. Chem. Rev. 2008, 108, 2592-3015. [CrossRef]

22. Chang, L.L.; Deng, L.D.; Wang, W.W.; Lv, Z.S.; Hu, F.Q.; Dong, A.J.; Zhang, J.H. Poly(ethyleneglycol)-b-Poly ( $\varepsilon$-caprolactone-co- $\gamma$-hydroxyl- $\varepsilon$-caprolactone) bearing pendant hydroxyl groups as nanocarriers for doxorubicin delivery. Biomacromolecules 2012, 13, 3301-3310. [CrossRef] [PubMed]

23. Thévenaz, D.C.; Monnier, C.A.; Balog, S.; Fiore, G.L. Luminescent nanoparticles with lanthanide-containing poly(ethylene glycol)-poly(E-caprolactone) block copolymers. Biomacromolecules 2014, 15, 3994-4001. [CrossRef] [PubMed]

24. Vidyasagar, A.; Ku, S.H.; Kim, M.; Kim, M.; Lee, H.S.; Pearce, T.R.; McCormick, A.V.; Bates, F.S.; Kokkoli, E. Design and characterization of a PVLA-PEG-PVLA thermosensitive and biodegradable hydrogel. ACS Macro Lett. 2017, 6, 1134-1139. [CrossRef]

25. Chandel, A.K.S.; Kumar, C.U.; Jewrajka, S.K. Effect of polyethylene glycol on properties and drug encapsulation-release performance of biodegradable/cytocompatible agarose-polyethylene glycol-polycaprolactone amphiphilic co-network gels. ACS Appl. Mater. Interfacs. 2016, 8, 3182-3192. [CrossRef] [PubMed]

26. He, J.P.; Chen, J.Z.; Lin, S.L.; Niu, D.C.; Hao, J.; Jia, X.B.; Li, N.; Gu, J.L.; Li, Y.S.; Shi, J.L. Synthesis of a pillar[5] arene-based polyrotaxane for enhancing the drug loading capacity of PCL-based supramolecular amphiphile as an excellent drug delivery platform. Biomacromolecules 2018, 19, 2923-2930. [CrossRef] [PubMed]

27. Jain, E.; Hill, L.; Canning, E.; Sell, S.A.; Zustiak, S.P. Control of gelation, degradation and physical properties of polyethylene glycol hydrogels through the chemical and physical identity of the crosslinker. J. Mater. Chem. B 2017, 5, 2679-2691. [CrossRef]

28. Blackwell, C.J.; Haernvall, K.; Guebitz, G.M.; Groombridge, M.; Gonzales, D.; Khosravi, E. Enzymatic degradation of star poly( $\varepsilon$-caprolactone) with different central units. Polymers 2018, 10, 1266. [CrossRef] [PubMed] 
29. Liu, S.X.; Li, X.; Guang, N.E.; Tian, L.; Mao, H.G.; Ning, W.Y. Novel amphiphilic temperature responsive graft copolymers PCL-g-P(MEO 2 MA-co- OEGME) via a combination of ROP and ATRP: Synthesis, characterization, and sol-gel transition. J. Polym. Res. 2016, 23, 141-153. [CrossRef]

30. Wang, Q.Q.; Liu, S.X.; Sheng, W.J.; Guang, N.E.; Li, X. Synthesis and sol-gel transition of novel temperature responsive ABA triblock-graft copolymers based on PCL and PEG analogues. Macromol. Res. 2015, 23, 607-617. [CrossRef]

31. Lutz, J.-F.; Weichenhan, K.; Akdemir, Ö.; Hoth, A. About the phase transitions in aqueous solutions of thermoresponsive copolymers and hydrogels based on 2-(2-methoxyethoxy)ethyl methacrylate and oligo(ethylene glycol) methacrylate. Macromolecules 2007, 40, 2503-2508. [CrossRef]

32. Lin, W.C.; Liou, S.H.; Kotsuchibashi, Y. Development and characterisation of the imiquimod poly(2-(2-methoxyethoxy)ethyl methacrylate) hydrogel dressing for keloid therapy. Polymers 2017, 9, 579. [CrossRef] [PubMed]

33. Sun, S.T.; Wu, P.Y. On the thermally reversible dynamic hydration behavior of oligo(ethylene glycol) methacrylate-based polymers in water. Macromolecules 2013, 46, 236-246. [CrossRef]

34. Xu, L.Q.; Yao, F.; Fu, G.D.; Kang, E.T. Interpenetrating network hydrogels via simultaneous "click chemistry" and atom transfer radical polymerization. Biomacromolecules 2010, 11, 1810-1817. [CrossRef] [PubMed]

35. Lenoir, S.; Riva, R.; Lou, X.; Detrembleur, C.; Jérôme, R.; Lecomte, P. Ring-opening polymerization of $\alpha$-chloro- $\varepsilon$-caprolactone and chemical modification of poly $(\alpha$-chloro- $\varepsilon$-caprolactone) by atom transfer radical processes. Macromolecules 2004, 37, 4055-4061. [CrossRef]

36. Chen, J.C.; Liu, M.Z.; Gao, C.M.; Lü, S.Y.; Zhang, X.Y.; Liu, Z. Self-assembly behavior of pH- and thermo-responsive hydrophilic ABCBA-type pentablock copolymers synthesized by consecutive RAFT polymerization. RSC Adv. 2013, 3, 15085-15093. [CrossRef]

37. Lutz, J.F.; Hoth, A. Preparation of Ideal PEG Analogues with a Tunable Thermosensitivity by Controlled Radical Copolymerization of 2-(2-Methoxyethoxy) ethyl Methacrylate and Oligo(ethylene glycol) Methacrylate. Macromolecules 2006, 39, 893-896. [CrossRef]

38. Mishra, A.K.; Vishwakarma, N.K.; Patel, V.K.; Biswas, C.S.; Paira, T.K.; Mandal, T.K.; Maiti, P.; Ray, B. Synthesis, characterization, and solution behavior of well-defined double hydrophilic linear amphiphilic poly ( $N$-isopropylacrylamide)- $b$-poly ( $\varepsilon$-caprolactone)- $b$-poly ( $N$-isopropylacrylamide) triblock copolymers. Colloid Polym. Sci. 2014, 292, 1405-1418. [CrossRef]

39. Ning, W.Y.; Shang, P.; Wu, J.; Shi, X.Y.; Liu, S.X. Novel amphiphilic, biodegradable, biocompatible, thermo-responsive ABA triblock copolymers based on PCL and PEG analogues via a combination of ROP and RAFT: Synthesis, characterization, and sustained drug release from self-assembled micelles. Polymers 2018, 10, 214. [CrossRef]

40. Zhao, Y.P.; He, G.Q.; Guo, W.H.; Bao, L.L.; Yi, M.J.; Gong, Y.K.; Zhang, S.P. Self-assembled micelles prepared from amphiphilic copolymers bearing cell outer membrane phosphorylcholine zwitterions for a potential anti-phagocytic clearance carrier. Polym. Chem. 2016, 7, 5698-5708. [CrossRef]

41. Li, S.S.; Chen, G.X.; Zhou, Z.; Li, Q.F. Stimuli-induced multiple dissociation and micellization transitions of random copolymers. RSC Adv. 2015, 5, 65847-65855. [CrossRef]

42. Jin, N.X.; Zhang, H.; Jin, S.; Dadmun, M.D.; Zhao, B. Tuning of thermally induced sol-to-gel transitions of moderately concentrated aqueous solutions of doubly thermosensitive hydrophilic diblock copolymers poly(methoxytri(ethylene glycol) acrylate)-b-poly(ethoxydi(ethylene glycol) acrylate-co-acrylic acid). J. Phys. Chem. B 2012, 116, 3125-3137. [CrossRef] [PubMed]

43. Jin, C.; Song, W.J.; Liu, T.; Xin, J.N.; Zhang, J.W. Temperature and pH Responsive Hydrogels Using Methacrylated Lignosulfonate Cross-Linker: Synthesis, Characterization, and Properties. ACS Sustain. Chem. Eng. 2018, 6, 1763-1771. [CrossRef]

44. Sheng, W.J.; Liu, T.; Liu, S.X.; Wang, Q.Q. Temperature and pH responsive hydrogels based on polyethylene glycol analogues and poly(methacrylic acid) via click chemistry. Polym. Int. 2015, 64, 1415-1424. [CrossRef]

(C) 2019 by the authors. Licensee MDPI, Basel, Switzerland. This article is an open access article distributed under the terms and conditions of the Creative Commons Attribution (CC BY) license (http://creativecommons.org/licenses/by/4.0/). 